\title{
Research on the properties of high chromium cast iron overlay welds deposited by tubular electrodes
}

\begin{abstract}
Keywords:

hardfacing;

tubular electrodes;

covered electrodes;

abrasion;

chromium cast iron

In the paper, there were shown the results of research on the properties of overlay welds consisted of one and three layers deposited by three types of tubular electrodes of the Fe-Cr-C alloy, Fe-Cr-C-Nb-Mo-W-V alloy and composite consist of tungsten carbide particles in the Fe-Cr-C alloy matrix. The study of hardfacing deposits included: test of metal-mineral abrasion resistance, metallographic examinations, analysis of chemical composition, and hardness tests. The test of abrasive usage in metal-mineral friction was made according to the procedure A of the ASTM G 65 standard.
\end{abstract}

\section{Introduction}

The wear of equipment and machinery parts restricts their service life. The replacement of a useless element entails replacement costs (e.g. removal, fixing, transport, storage etc.) and production down times, potentially generating high losses $[1,2]$.

Surfacing is a popular method used when repairing worn machinery parts, often without the removal of the latter. Because of a significant range of electrodes and relatively low cost and simple equipment, one of the most popular hardfacing methods is manual metal arc overlay welding performed using a solid rod electrode or a tubular electrode [1 $\div 5]$.

Similar to conventional electrodes, tubular core electrodes are provided with a coating (usually thin) and a core (thin-walled tube or a coiled metal strip filled with powder) (Fig. 1).

Covered tubular electrodes in comparison to covered solid rod core electrodes are characterized by following pro-

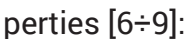

- possibility of obtaining overlay welds characterised by high quality and very high content of alloying components already in the first layer;

- higher deposition coefficient and a higher metal recovery;

- shallower penetration and lower dilution (for the same deposition rate);

- lower current values necessary for stable welding (in relation to the same diameters) and, consequently, a lower

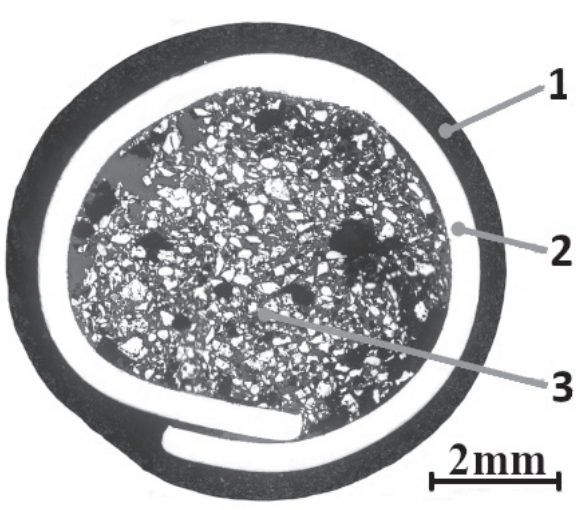

Fig. 1. The cross-sections of covered tubular electrode with a seam, $6.0 \mathrm{~mm}$ in diameter type Hardface HC-TE; 1 - coating, 2 - metal strip, 3 - powder core

heat input;

- unnecessity of storing in special conditions and pre-baking before the use.

Tubular electrodes are used, among other things, to deposit overlay welds resistant to abrasive wear in metal-mineral friction conditions. Catalogue data concerning electrodes refer to their classification, the chemical composition of the weld metal, hardness after the deposition of the third layer or the hardness of the weld deposit as well as exemplary applications. However, available reference publications do not contain 
information regarding abrasive wear resistance coefficients, particularly useful when selecting electrodes providing weld deposits belonging to, e.g. high-chromium cast irons. The above-named group includes, among others, alloys Fe1 6 and Fe20 according to PN-EN 14700:2014-06 [10]. The study aims to compare metal-mineral resistance type abrasive wear of overlay welds made using Hardface HC-TE, Hardface CNV-TE and Hardface STEELCARBW45-TE tubular electrodes (Welding Alloys), rated among filler metals characterised by high-chromium cast iron weld deposits, yet varying in their structure, chemical composition and hardness [9]. The scope of research-related tests included macroscopic metallographic tests, the identification of the content of the base material in the overlay welds, chemical composition analysis, hardness measurements concerning overlay weIds as well as microscopic metallographic tests of one and three-layer overlay welds.

\section{Materials and hardfacing parameters}

The chemical composition and the hardness of the weld deposit (provided by the manufacturer) obtained using the test tubular electrodes are presented in Table I.

The overlay welds were deposited on test plates $(200 \mathrm{x}$ $\times 150 \times 10 \mathrm{~mm}$ ) made of structural steel S355N (Table II). The hardfacing process was performed, in the flat position, and a straight polarity DC of $130 \mathrm{~A}$ following the manufacturers recommendations [9]. The length of arc maintained during the process amounted to approximately $3 \mathrm{~mm}$. The overlay welds were made manually, using a travel speed of approximately $12 \mathrm{~cm} / \mathrm{min}$ and an angle of approximately $15^{\circ}$, at which the electrode was inclined in relation to the perpendicular, in the direction of hardfacing. Two series of overlay welds were made using each electrode. Because of the significant effect of dilution on the properties of overlay weIds, in the first series one layer was deposited (high dilution) whereas in the second series three layers were deposited (low dilution). Each layer was composed of five stringer beads, whereas the hardfacing overlap constituted approximately $30 \%$ of the bead width.

\section{Abrasive wear resistance tests}

The metal-mineral type abrasive wear tests of one and three-layer overlay welds were performed in accordance with ASTM G 65, procedure A [11]. Before the tests, the overlay weld surfaces were subjected to grinding. During the tests, the abrasive flow rate was restricted within the range of $300 \mathrm{~g} / \mathrm{min}$ to $400 \mathrm{~g} / \mathrm{min}$. The specimens were subjected to a constant force of $130 \mathrm{~N}$. The abrasive wheel rotated at a rate of $200 \mathrm{rpm}$, where the abrasion distance amounted to $4309 \mathrm{~m}$. The abrasive material was dried quartz sand of spherically-shaped grains and characterised by granularity restricted within the range of $100 \mu \mathrm{m}$ to $300 \mu \mathrm{m}$. The identification of the abrasive wear resistance of the overlay weIds required the performance of measurements concerning mass loss and specimen density. For this purpose, before and after the tests, the specimens were weighed using a laboratory balance with an accuracy of up to $0.0001 \mathrm{~g}$. The average density of the overlay welds was determined using the laboratory balance. The identification of the average density was based on three density measurements involving the specimens weighed in the air and in the liquid. Mass loss was identified using the values of the average specimen mass loss and the average values of overlay weld density measured using formula (1). A reference material used in the abrasive wear resistance test was abrasion-resistant steel HARDOX 450 (Table II). The results obtained in the tests are presented in Table III.

$$
V_{l}=\frac{M_{l}}{\rho} \cdot 1000
$$

$\mathrm{V}_{1}$ - volume loss, $\mathrm{mm}^{3}$;

$\mathrm{M}_{1}$ - mass loss, g;

$\rho$ - density, $\mathrm{g} / \mathrm{cm}^{3}$.

\section{Determination of dilution}

Geometrical dimensions of the overlay welds were determined on the basis on specimen macrostructure photographs, using a software programme. The dilution was determined using the geometrical method and formula (2). The results concerning the measurements of the cross-sectional areas of the fusion and of excess overlay weld metal as well as results related to dilution are presented in Table IV.

$$
D=\frac{A_{b m}}{A_{b m}+A_{r}} \cdot 100 \%
$$

D - dilution, \%;

$\mathrm{A}_{\mathrm{bm}}$ - area of base metal melted, $\mathrm{mm}^{2}$;

$A_{r}$ - area of reinforcement of the deposit, $\mathrm{mm}^{2}$.

\section{Hardness tests}

The hardness of the overlay welds and that of reference material (steel HARDOX 450) was measured using the Rockwell

\begin{tabular}{|c|c|c|c|c|c|c|c|c|c|}
\hline \multirow{2}{*}{ Designation (hardness) } & \multicolumn{9}{|c|}{ Chemical composition, wt. \% } \\
\hline & $\mathrm{Fe}$ & C & Mn & Si & $\mathrm{Cr}$ & Mo & $\mathrm{Nb}$ & $\mathbf{V}$ & $\mathbf{W}$ \\
\hline HC-TE (61 HRC) & rest & 5.8 & 0.9 & 0.8 & 30.0 & - & - & - & - \\
\hline CNV-TE (65 HRC) & rest & 6.0 & 1.0 & 0.9 & 20.0 & 5.0 & 6.0 & 1.2 & 1.5 \\
\hline STEELCARBW45-TE* (65 HRC) & rest & 3.5 & 0.8 & 0.8 & 15.0 & - & - & - & - \\
\hline
\end{tabular}

Table I. Chemical composition and hardness of tested tubular electrodes deposited metal [9]

\begin{tabular}{|c|c|c|c|c|c|c|c|c|}
\hline \multirow{2}{*}{$\begin{array}{l}\text { Designation of base material } \\
\text { and reference material }\end{array}$} & \multicolumn{8}{|c|}{ Chemical composition, wt. \% } \\
\hline & $\mathrm{Fe}$ & C & Mn & Si & $\mathrm{Cr}$ & $\mathrm{Ni}$ & Mo & B \\
\hline S355N & rest & $\max .0 .24$ & $\max .1 .6$ & $\max .0 .55$ & - & - & - & - \\
\hline HARDOX 450 & rest & 0.26 & 1.6 & 0.7 & 1.4 & 1.5 & 0.6 & 0.005 \\
\hline
\end{tabular}

Table II. Chemical composition of base material and the reference material for abrasion resistance tests 
hardness test performed in accordance with the PN-EN ISO 6508-1:2016-10 standard. Each specimen was subjected to five measurements involving the ground surface of the overlay weld face (Fig. 2). The test results are presented in Table V.

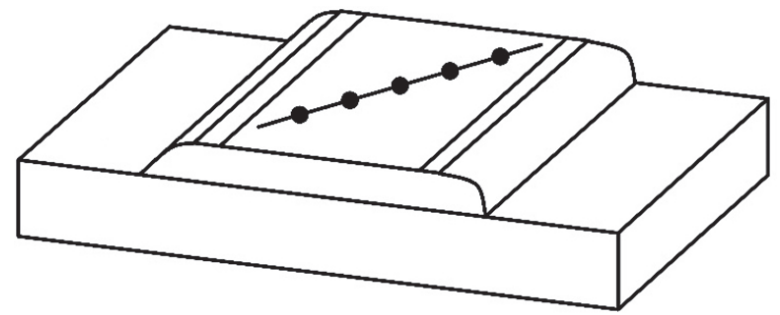

Fig. 2. Measurement points distribution in hardness tests on the face of the overlay weld

\section{Chemical composition analysis}

The analysis of the chemical composition involved the use of spark source optical emission spectrometry. Each specimen was subjected to three chemical composition measurements involving the ground surface of the overlay weld face (Fig. 2). The average content of chemical elements are presented in Table VI.

\section{Microscopic metallographic tests}

The structure of the deposited layers was identified in microscopic metallographic tests performed using light microscopy. In addition, based on photographs of the microstructure

Table III. Results of metal-mineral abrasion resistance test of tubular electrodes overlay welds and Hardox 450 steel

\begin{tabular}{|c|c|c|c|c|c|c|}
\hline Specimen designation & $\begin{array}{l}\text { Number } \\
\text { of layers }\end{array}$ & Mass loss, $\mathrm{g}$ & $\begin{array}{l}\text { Average mass } \\
\text { loss, } \mathrm{g}\end{array}$ & $\begin{array}{l}\text { Average density, } \\
\mathrm{g} / \mathrm{cm}^{3}\end{array}$ & $\begin{array}{l}\text { Average volume } \\
\text { loss, } \mathrm{mm}^{3}\end{array}$ & $\begin{array}{l}\text { Relative abrasive } \\
\text { wear resistance* }\end{array}$ \\
\hline \multirow[b]{2}{*}{ HARDOX 450} & - & 0.6699 & \multirow{2}{*}{0.6685} & \multirow[b]{2}{*}{7.7436} & \multirow[b]{2}{*}{86.3294} & \multirow[b]{2}{*}{1.00} \\
\hline & - & 0.6671 & & & & \\
\hline \multirow{2}{*}{ HC-TE-1 } & 1 & 0.3271 & \multirow{2}{*}{0.3185} & \multirow{2}{*}{7.3430} & \multirow{2}{*}{43.3746} & \multirow{2}{*}{1.99} \\
\hline & 1 & 0.3099 & & & & \\
\hline \multirow{2}{*}{ HC-TE-3 } & 3 & 0.1388 & \multirow{2}{*}{0.1339} & \multirow{2}{*}{7.1246} & \multirow{2}{*}{18.7940} & \multirow{2}{*}{4.59} \\
\hline & 3 & 0.1290 & & & & \\
\hline \multirow{2}{*}{ CNV-TE-1 } & 1 & 0.2558 & \multirow{2}{*}{0.2491} & \multirow{2}{*}{7.3962} & \multirow{2}{*}{33.6795} & \multirow{2}{*}{2.56} \\
\hline & 1 & 0.2424 & & & & \\
\hline \multirow{2}{*}{ CNV-TE-3 } & 3 & 0.1001 & \multirow{2}{*}{0.1022} & \multirow{2}{*}{7.2110} & \multirow{2}{*}{14.1728} & \multirow{2}{*}{6.09} \\
\hline & 3 & 0.1043 & & & & \\
\hline \multirow{2}{*}{ STEELCARBW45-TE-1 } & 1 & 0.2772 & \multirow{2}{*}{0.2694} & \multirow{2}{*}{8.2695} & \multirow{2}{*}{32.5775} & \multirow{2}{*}{2.65} \\
\hline & 1 & 0.2616 & & & & \\
\hline \multirow{2}{*}{ STEELCARBW45-TE-3 } & 3 & 0.1242 & \multirow{2}{*}{0.1290} & \multirow{2}{*}{9.3853} & \multirow{2}{*}{13.7449} & \multirow{2}{*}{6.28} \\
\hline & 3 & 0.1338 & & & & \\
\hline
\end{tabular}

Table IV. The dilution level of overlay welds deposited by tubular electrodes

\begin{tabular}{|c|c|c|c|c|c|}
\hline Specimen designation & $\begin{array}{l}\text { Number } \\
\text { of layers }\end{array}$ & $\begin{array}{l}\text { Area of base metal } \\
\text { melted, } \mathrm{mm}^{2}\end{array}$ & $\begin{array}{l}\text { Area of reinforcement } \\
\text { of the deposit, } \mathrm{mm}^{2}\end{array}$ & Dilution, \% & Average dilution, $\%$ \\
\hline \multirow{2}{*}{ HC-TE-1 } & 1 & 22.7921 & 87.2726 & 20.7 & \multirow{2}{*}{20.9} \\
\hline & 1 & 19.6349 & 73.2806 & 21.1 & \\
\hline \multirow{2}{*}{ HC-TE-3 } & 3 & 17.9770 & 202.5833 & 8.2 & \multirow{2}{*}{8.6} \\
\hline & 3 & 23.4652 & 235.9865 & 9.0 & \\
\hline \multirow{2}{*}{ CNV-TE-1 } & 1 & 20.1678 & 81.5378 & 19.8 & \multirow{2}{*}{22.4} \\
\hline & 1 & 24.2885 & 72.6987 & 25.0 & \\
\hline \multirow{2}{*}{ CNV-TE-3 } & 3 & 20.1991 & 219.1866 & 8.4 & \multirow{2}{*}{8.8} \\
\hline & 3 & 25.4401 & 250.1980 & 9.2 & \\
\hline \multirow{2}{*}{ STEELCARBW45-TE-1 } & 1 & 19.4258 & 61.5623 & 24.0 & \multirow{2}{*}{22.9} \\
\hline & 1 & 21.0165 & 74.9647 & 21.9 & \\
\hline \multirow{2}{*}{ STEELCARBW45-TE-3 } & 3 & 18.0433 & 220.3653 & 7.6 & \multirow{2}{*}{9.8} \\
\hline & 3 & 27.0511 & 199.5324 & 11.9 & \\
\hline
\end{tabular}


of the cross-sections of the overlay welds made using the Hardface STEELCARBW45-TE electrodes, the size of tungsten carbides was identified using a related software programme. The size of the tungsten carbides was restricted within the range of approximately $30 \mu \mathrm{m}$ to $260 \mu \mathrm{m}$. The carbides were present at the bottom part of the deposited overlay weld. Figure 3 presents the microstructures of the deposited overlay welds.
The analysis of the chemical composition, microscopic test results and reference scientific publications revealed that the deposited layers contained chromium carbides in austenitic matrix (Hardface HC-TE) as well as chromium carbides and complex carbides of niobium, molybdenum, vanadium and tungsten (Hardface CNV-TE) as well as tungsten carbide grains and carbides of tungsten and chromium in martensitic matrix (Hardface STEELCARBW45-TE) [7,9].

Table V. Results of HRC hardness measurements on the face of the tubular electrodes overlay weld

\begin{tabular}{|c|c|c|c|c|c|c|c|c|}
\hline \multirow{2}{*}{ Specimen designation } & \multirow{2}{*}{$\begin{array}{l}\text { Number } \\
\text { of layers }\end{array}$} & \multicolumn{5}{|c|}{ Hardness test point } & \multirow{2}{*}{$\begin{array}{c}\text { Average hardness, } \\
\text { HRC }\end{array}$} & \multirow{2}{*}{$\begin{array}{c}\text { Average hardness, } \\
\text { HRC }\end{array}$} \\
\hline & & 1 & 2 & 3 & 4 & 5 & & \\
\hline \multirow{2}{*}{ HC-TE-1 } & 1 & 59.2 & 60.1 & 57.9 & 59.7 & 60.0 & 59.4 & \multirow{2}{*}{59.1} \\
\hline & 1 & 58.6 & 60.4 & 55.9 & 60.2 & 59.4 & 58.9 & \\
\hline \multirow{2}{*}{ HC-TE-3 } & 3 & 61.7 & 62.3 & 61.1 & 62.1 & 62.2 & 61.9 & \multirow{2}{*}{61.8} \\
\hline & 3 & 62.4 & 60.8 & 61.8 & 61.5 & 62.0 & 61.7 & \\
\hline \multirow{2}{*}{ CNV-TE-1 } & 1 & 58.7 & 61.0 & 60.4 & 59.7 & 59.1 & 59.8 & \multirow{2}{*}{59.6} \\
\hline & 1 & 60.7 & 57.9 & 60.1 & 59.7 & 58.9 & 59.5 & \\
\hline \multirow{2}{*}{ CNV-TE-3 } & 3 & 61.7 & 61.8 & 62.8 & 62.4 & 63.0 & 62.3 & \multirow{2}{*}{62.5} \\
\hline & 3 & 63.7 & 60.9 & 63.4 & 63.8 & 61.6 & 62.7 & \\
\hline \multirow{2}{*}{ STEELCARBW-45-TE-1 } & 1 & 57.6 & 60.2 & 60.4 & 59.7 & 59.3 & 59.4 & \multirow{2}{*}{59.4} \\
\hline & 1 & 60.2 & 58.1 & 57.9 & 60.1 & 60.0 & 59.3 & \\
\hline \multirow{2}{*}{ STEELCARBW-45-TE-3 } & 3 & 60.7 & 65.2 & 63.7 & 62.6 & 62.9 & 63.0 & \multirow{2}{*}{63.2} \\
\hline & 3 & 61.4 & 62.9 & 65.0 & 64.2 & 63.4 & 63.4 & \\
\hline \multirow{2}{*}{ HARDOX 450} & - & 45.3 & 40.3 & 43.9 & 44.5 & 45.4 & 43.9 & \multirow{2}{*}{43.8} \\
\hline & - & 45.2 & 45.3 & 43.7 & 42.7 & 41.8 & 43.7 & \\
\hline
\end{tabular}
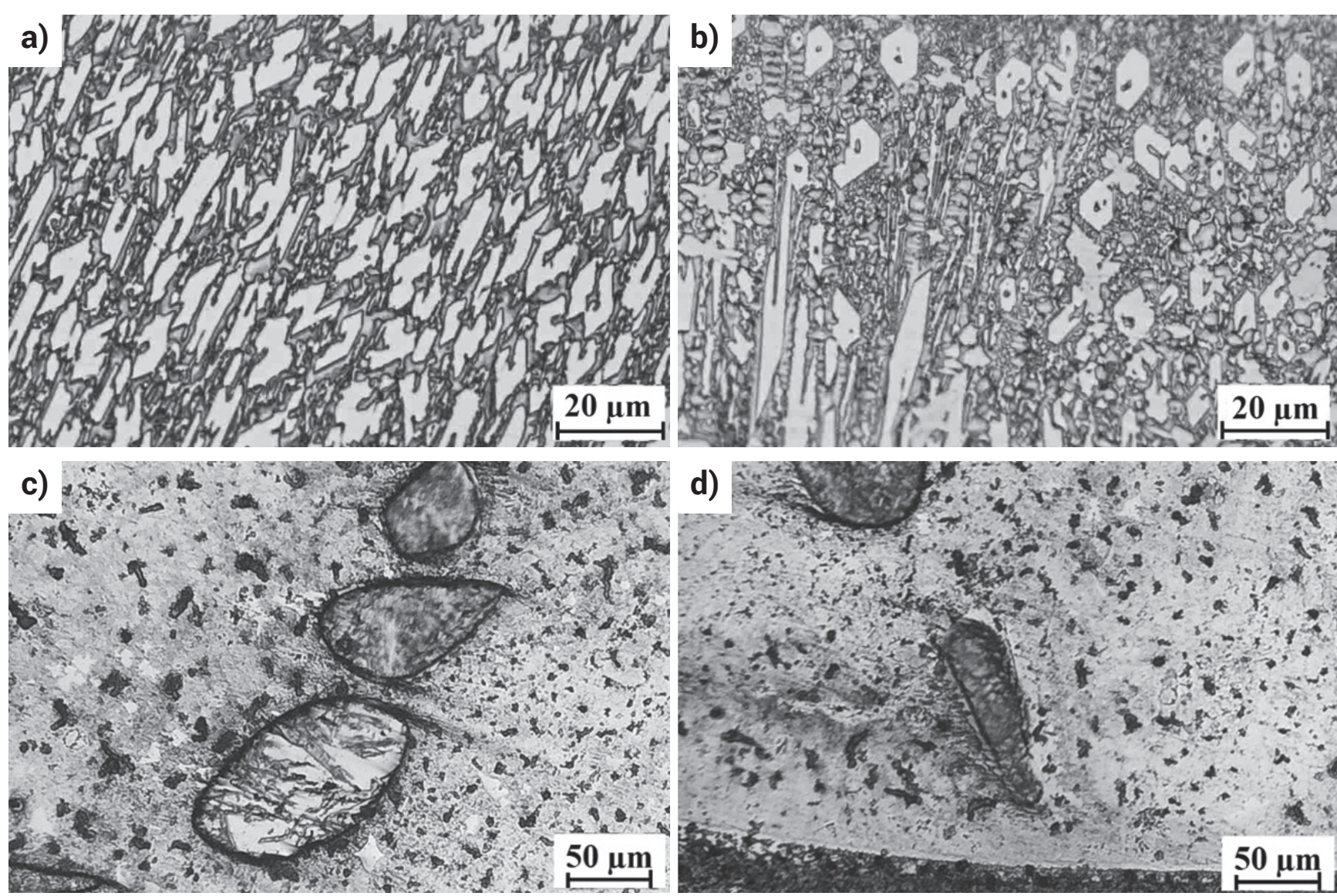

Fig. 3. Microstructures of overlay welds deposited by tubular electrodes: a) Hardface HC-TE third layer, b) Hardface CNV-TE third layer, c) Hardface STEELCARBW45-TE third layer, d) Hardface STEELCARBW45-TE first layer, fusion zone 
Table VI. Results of chemical composition analysis of the tubular electrodes overlay weld

\begin{tabular}{|c|c|c|c|c|c|c|c|c|c|c|}
\hline \multirow{2}{*}{$\begin{array}{l}\text { Designation of the } \\
\text { sample }\end{array}$} & \multirow{2}{*}{$\begin{array}{l}\text { Number } \\
\text { of layers }\end{array}$} & \multicolumn{9}{|c|}{ Chemical composition, wt. \% } \\
\hline & & $\mathrm{Fe}$ & C & Mn & Si & $\mathrm{Cr}$ & Mo & $\mathrm{Nb}$ & $\mathbf{v}$ & w \\
\hline HC-TE-1 & 1 & reszta & 3.42 & 1.0 & 1.0 & 20.96 & 0.04 & 0.01 & 0.04 & $<0.01$ \\
\hline HC-TE-3 & 3 & reszta & 5.82 & 0.9 & 1.2 & 30.09 & 0.04 & 0.02 & 0.04 & $<0.01$ \\
\hline CNV-TE-1 & 1 & reszta & 3.11 & 1.3 & 1.2 & 13.52 & 2.93 & 3.64 & 0.88 & 0.68 \\
\hline CNV-TE-3 & 3 & reszta & 5.50 & 1.9 & 1.6 & 18.85 & 4.58 & 5.92 & 1.28 & 1.18 \\
\hline STEELCARBW45-TE-1 & 1 & reszta & 2.17 & 0.8 & 1.2 & 10.35 & 0.68 & 0.02 & 0.17 & 40.30 \\
\hline STEELCARBW45-TE-3 & 3 & reszta & 4.01 & 0.6 & 1.8 & 15.21 & 0.08 & 0.18 & 0.03 & 41.90 \\
\hline
\end{tabular}

\section{Summary}

The test results revealed that the use of the tubular electrodes having a diameter of $6.0 \mathrm{~mm}$ and a current of $130 \mathrm{~A}$ causes the dilution in the one-layer overlay welds restricted within the range of 19.8 to $25.0 \%$. In turn, in the three-layer overlay welds, the dilution was restricted within the range of 8.6 to $9.8 \%$.

The average hardness in the first overlay weld layer was restricted within the range of 58.9 to 59.8 HRC. An increase in the number of layers, combined with a resultant decrease in dilution, was accompanied by an increase in the hardness of the overlay welds. As regards to the three-layer overlay welds made using the Hardface electrodes, the hardness was restricted within the range of 61.7 to $61.9 \mathrm{HRC}$ (HC-TE), 62.3 to $62.7 \mathrm{HRC}$ (CNV-TE) and 63.0 to $63.4 \mathrm{HRC}$ (STEELCARBW45-TE). The average hardness of the specimens made of steel HARDOX 450 was amounted to $43.8 \mathrm{HRC}$.

Similar to hardness, the content of alloying elements was higher in the third layer than that in the first one. It was noticed that the chemical composition of the three-layer overlay welds made using the tubular electrodes was similar or the same as that declared by the manufacturer of the filler metals in relation to five-layer overlay welds (weld deposit) [9]. The increased content of carbon in the three-layer overlay welds and tungsten in the one-layer and in the three-layer overlay welds made using the Hardface STEELCARBW45-TE electrodes could be ascribed to the partial dissolution of tungsten carbide contained in the core. It was ascertained that tungsten carbides were predominantly present in the lower parts of the overlay weld beads, which could be attributed to the higher density of the former than that of the matrix metal.

The metallographic tests confirmed information contained in reference publications, whereby it was possible to obtain porosity-free overlay welds without the necessity of pre-baking tubular electrodes before hardfacing. In the overlay welds made using the covered solid-cored electrodes, containing tungsten carbides of similar granularity (in the coating), tungsten carbides dissolved entirely during hardfacing [5]. In turn, the one and three-layer overlay welds made using the Hardface STEELCARBW45-TE tubular electrodes contained undissolved tungsten carbides (WC).

In terms of hardness, content of alloying elements and metal-mineral type abrasive wear resistance, the three-layer overlay welds were characterised by superior properties. The highest relative abrasive wear resistance was that of the overlay weld made using the Hardface STEELCARBW45-TE electrode. The above-named specimen was 6.28 times more resistant to abrasion than the reference specimen made of steel HARDOX 450. Similarly high resistance to abrasive wear (i.e. more than six times) was characteristic of the three-layer overlay weld made using Hardface CNV-TE electrode. The third layer of the specimen made using the Hardface HC-TE electrode was 4.59 times more resistant to abrasive wear than HARDOX 450 . The relative abrasive wear resistance of the one-layer overlay welds determined in accordance with the ASTM G 65 standard was 2.65 (Hardface STEELCARBW45-TE), 2.56 (Hardface CNV-TE) and 1.99 (Hardface HC-TE) times higher than the resistance of the reference specimen.

It was ascertained that when determining the relative metal-mineral type abrasive wear resistance in accordance with ASTM G 65 based solely on mass loss, obtained values differed from those taking into consideration both the mass loss and the density of a given test specimen. The use of volume loss in abrasive wear resistance tests is recommended in standard [11]. The tests concerning the properties of the overlay welds made using the tubular electrodes did not reveal the correlation between hardness and metal-mineral type abrasive wear resistance.

\section{References}

[1] V. Lazic, D. Arsic, R. Nikolic, M. Mutavzic, B. Hadzima, Revitalization of the damaged machine parts by hard facing as a way of saving funds, Production Engineering Archives (2016), vol. 12 (3), 9-13.

[2] D. Womersley, Hardfacing: not merely a reclamation process, Surface Engineering (1995), vol. 11 (1), 43-46.

[3] A. Klimpel, Napawanie i natryskiwanie cieplne. Technologie, WNT (2000), Warszawa, 92.

[4] A.K. Mangla, S. Singh, J.S. Grewal, V. Chawla, Improvement in abrasive wear resistance by hardfacing: a review, National Conference on Advancements and Futuristic Trends in Mechanical and Materials Engineering (2010), 90-95.

[5] J. Węgrzyn, Elektrody kompozytowe z węglikiem wolframu w otulinie, Welding Technology Review (1995), vol. 47 (12), 5-9.
[6] A. Gruszczyk, Kształtowanie struktury napoin żeliwnych przez podwyższenie ich zdolności do grafityzacji, Welding Technology Review (2011), vol. 83 (10), 61-66.

[7] A. Klimpel, A. Gruszczyk, K. Luksa, A. Szymański, Otulone elektrody rurkowe do napawania, Welding Technology Review (1995), vol. 47 (4), 1-4.

[8] A. Cruz-Crespo, A. Scotti, M. Rodriguez-Perez, Operational behavior assesment of coated tubular electrodes for SMAW hardfacing, Journal of Materials Processing Technology (2008), vol. 199, 265-273.

[9] Katalog firmy Welding Alloys Polska Sp. z o.o., Elektrody rurkowe WA do napawania, 2017

[10] Norma PN-EN 14700:2014-06 Materiały dodatkowe do spawania - Materiały dodatkowe do napawania utwardzającego.

[11] Norma ASTM G 65-00 Standard Test Method for Measuring Abrasion Using the Dry Sand/Rubber Wheel Apparatus. 